\title{
SUSCEPTIBILITY PATTERN OF PSEUDOMONAS AERUGINOSA PRODUCING ENZYMES AGAINST ANTIMICROBIAL AGENT CELL FREE SUPERNATANT OF LACTOCOCCUS WITH THE FOCUS ON ITS DETERMINING QUANTITATIVELY BY OD (ENZYME LINKED IMMUNE SORBENT ASSAY)
}

\author{
YUSRA MB MOHSIN*, HUDA ZUHEIR MAJEED, ALI MURTATHA HASAN, ENAAM HAMED BATAAH \\ Department of Biology, College of Science, Al-Mustansiriyah University, Baghdad, Iraq. Email: usra_ali75@yahoo.com
}

Received: 15 November 2016, Revised and Accepted: 24 December 2016

ABSTRACT

Objective: The present work was conducted to explore the prevalence of Pseudomonas aeruginosa that produce lipase and protease enzymes in 40 samples, as well as detection of quality and quantity production and determine its susceptibility to antimicrobial.

Methods: The antimicrobial activity of Lactococcus cell free supernatant (CFS) on P. aeruginosa growth and quantity production of enzymes by two methods (special media and OD) were also studied.

Results: A total of $8(20 \%)$ and $13(32 \%)$ isolates were found to be positive to P. aeruginosa producing lipase and protease, respectively. The in vitro antimicrobial activity results revealed that all isolates producing enzymes showed sensitive to CFS of Lactococcus, only one isolate exhibited low sensitivity to CFS $4 \mathrm{~mm}$, however, these isolates varied in their sensitivity to CFS ranged 4-15 mm.

Conclusion: Results of the quantity production of $P$. aeruginosa enzymes with CFS of Lactococcus showed and exerts growth inhibitory activity and reduce the production of enzymes. We could be concluded that CFS of Lactococcus has great potential antimicrobial activity against P. aeruginosa growth and its ability on enzymes production.

Keywords: Pseudomonas aeruginosa, Lactococcus, Cell-free supernatant, Optical density, Lipase, Protease.

(c) 2017 The Authors. Published by Innovare Academic Sciences Pvt Ltd. This is an open access article under the CC BY license (http://creativecommons. org/licenses/by/4. 0/) DOI: http://dx.doi.org/10.22159/ajpcr.2017.v10i3.16188

\section{INTRODUCTION}

Pseudomonas aeruginosa is an opportunistic pathogen as it initiates resistance to many antibiotics and disinfectant, in addition to its armory of putative virulence factors plus plasmid acquired resistance [1,2]. Pseudomonas aeruginosa produced as the large array of colonized and virulence factors like lipase and protease enzymes production allowing it to make different types of infections [3].

It is well recognized that the intensive use of antibiotics contributes to the development of antibiotic resistance; moreover, antibiotics can be harmful to human and are associated with increased rates of mortality and morbidity [4]. In another side, the intensive use of probiotics lactic acid bacteria (LAB) has received increased during the last few decades [5]. Probiotics are defined as living microorganisms, which are safe for human, the major strain Lactococcus is the most dominant bacteria in the small and large intestine of humans [6]. LAB including Lactococcus spp. is gaining increasing interesting worldwide to be used in the prevention, control and treatment of disease, and health maintenance [7]. Considering the above facts in mind, this study was undertaken to determine the antimicrobial activity of Lactococcus casei against $P$. aeruginosa growth and its quality and quantity productivity to lipase and protease by two methods (using special media and optical density (OD) method).

\section{METHODS}

Collection of the tested bacterium

A total of 40 isolates from $P$. aeruginosa are used in this study which brought from Medical City Hospital from wounded patients. The isolated bacteria were identified according to Forbes et al. [8] and stored until used in the study.
Lipase enzyme productivity of $P$. aeruginosa test

The investigation of lipase production (L.P) by P. aeruginosa isolates using tween 80 medium (Peptone $10 \mathrm{~g}+\mathrm{NaCl} 5 \mathrm{~g}+\mathrm{CaCl}_{2} 0.1 \mathrm{~g}+$ agar $20 \mathrm{~g}$ and tween $80 \mathrm{ml}$ with water $1000 \mathrm{ml}$ ), which inoculated with colonies that grow on brain heart infusion, these plates were incubated in $37^{\circ} \mathrm{C}$ for $24 \mathrm{hrs}$. The emergence of sediment around the colony indicating a positive result [9].

\section{Protease enzyme productivity of $P$. aeruginosa test}

Furthermore, to investigation of protease production (P.P) by P. aeruginosa isolates were performed using skim milk Columbia medium (Peptone $2.3 \mathrm{~g}+$ starch $0.1 \mathrm{~g}+\mathrm{NaCl} 0.5 \mathrm{~g}$, agar-agar $4 \mathrm{~g}$ and $100 \mathrm{ml}$ D.W with Ph7.5 $+100 \mathrm{ml}$ skim milk and mixing for 5 minutes, and put in plates) which inoculated by streaking with colonies that grown on brain heart infusion, these plates were incubated in $37^{\circ} \mathrm{C}$ for $24 \mathrm{hrs}$ The emergence of transparent areas around the colony indicating a positive result [9].

\section{Lactococcus isolate}

From Al-Mustansiriyah University/Science Collage/high studies laboratories, this isolate was obtained and identified again according to Forbes et al. [8].

Preparation of cell-free supernatant from Lactococcus strain Cell-free supernatant (CFS) was prepared according to Aminnezhad et al. [10]. Lactococcus was grown in MRS broth (pH 5.7) for $48 \mathrm{hrs}$ at $37^{\circ} \mathrm{C}$ in anaerobic condition. CFS was obtained by centrifugation the culture at $15,000 \mathrm{rpm}$ for 15 minutes at $4^{\circ} \mathrm{C}$ and then filtered through $0.45 \mu \mathrm{m}$ filters (Millipore, Bedford, MA).

Agar well diffusion assay

$P$. aeruginosa isolates after testing were submitted to enzymes productivity antibacterial assay of Lactococcus CFS by agar well diffusion that done as follows: 
A. Petri plates were prepared by pouring $20 \mathrm{ml}$ of respective sterile Mueller-Hinton media for test $P$. aeruginosa isolates and allowed it to solidify

B. Spreading of agar plates with $100 \mathrm{ml}$ of each standardized tested P. aeruginosa

C. Plates were allowed to dry and two wells (each $7 \mathrm{~mm}$ in diameter) made into agar plates with sterile borer

D. Wells loaded with $100 \mathrm{ml}$ of isolated bacterial culture filtrate supernatant and $100 \mathrm{ml}$ sterile broth

E. Plates were incubated at $37^{\circ} \mathrm{C}$ for $24 \mathrm{hrs}$ for test bacterial

F. Measurement of the diameter of the zone of inhibition with (mm) [11].

Estimate the quality production of $P$. aeruginosa enzymes

The quality of $P$. aeruginosa enzymes productivity was estimated using (mixing with culture media) method [12]. The test was done by adding CFS of Lactococcus (10\%) enzyme to productivity special medium each of lipase and protease that put in small vials (after sterilized and cooled), CFS was added to vials quietly and gently to prevent the formation of bubbles, then they were mixed well with vortex, pour the plate and left to cooled, and harden, each plate was inoculated with P. aeruginosa isolate that grown activity and incubated in $37^{\circ} \mathrm{C}$ for $24 \mathrm{hrs}$. After that, it has to know whether the isolates retained had the productivity of enzymes through the appearance or absence of a special indicator of each enzyme around the colony like it was mentioned previously. Medium without CFS used as negative control and the medium with CFS without inoculum used as positive control.

\section{Estimate the quantity production of $P$. aeruginosa enzymes}

The quantity of $P$. aeruginosa enzymes productivity was estimated using tissue culture plate method crystal violate staining (CV).

The experiment was done according to Hassan [13]. Briefly, the inoculum was prepared as described earlier, for each isolate, a loop full of activity growing cells was transferred to sterile Mueller-Hinton broth media. The OD of cells were determined for each suspension by enzyme-linked immune sorbent assay (ELISA) reader and adjusted to final OD $630 \mathrm{~nm}$. These cell suspensions were then used to grow and enzymes (L.P-P.P) production. For each strain, $200 \mathrm{ml}$ of the suspension was inoculated into individual wells of polystyrene of 96 well plates. MH broth not containing inoculum was used as a negative control. The plates were incubated at $37^{\circ} \mathrm{C}$ for $24 \mathrm{hrs}$ under aerobic conditions. Supernatant including planktonic cells and liquid medium was then discarded, and wells were gently washed twice with phosphate-buffered saline to a get ride on any non-adherent cells.

Adherent cells were fixed in $95 \%$ ethanol for 5 minutes and then ethanol was removed by air drying and stained with $1 \% \mathrm{CV}$ for 45 minutes. The OD values of stained adherent cells were determined by ELISA reader at $630 \mathrm{~nm}$. Lactococcus CFS and broth only was used as positive control.

Effect of Lactococcus CFS on P. aeruginosa enzymes productivity was quantified according to the above procedure. The extant of enzymes productivity degree was calculated according to the following equation:

Enzyme production (expressed as OD) $=$ OD test- OD control

The percentage of inhibition of productivity was calculated by the following formula:

Enzyme productivity $=\frac{\text { OD test }}{\text { OD control }}-$ OD test $* 100$

Chursi et al. [14] in all experiment, three replicates per treatment were used.

\section{RESULTS AND DISCUSSION}

In this studying, it was obtained $8(20 \%)$ isolates of $P$. aeruginosa producing of lipase and $13(32.5 \%)$ isolates P.P out of 40 isolates, while the same isolate did not repeat to possess both of enzymes in the same time (Table 1). This factor (enzymes production) is one of the virulence factors that added to other factors owned Pseudomonas especially P. aeruginosa $[15,16]$.

The antimicrobial activity of Lactococcus CFS is studied by well diffusion agar against 8 isolates (producing lipase) that called L.P. isolates and 13 isolates (P.P) also called P.P isolates (Table 2).

A total of 21 tested isolates (L.P. 8 + P.P. 13) were found to exhibit its effectiveness to CFS, the isolate of probiotic (Lactococcus) showed high inhibitory activity against two isolates (L.P. - 4 and P.P. - 1) with 15 minutes of both, whereas CFS gave lower inhibitory activity against just one isolate (L.P. 7) with $4 \mathrm{~mm}$, the rest of the pathogenic isolate showed inhibition ranged 4-15 $\mathrm{mm}$ for L.P. isolates and 7-15 $\mathrm{mm}$ for P.P. isolates (Fig. 1). The antimicrobial activity of Lactococcus CFS was may be due to the production of organic acids, reuterin, hydrogen peroxide, proteinaceous compounds, hydroxyl fatty acids, and phenolic compound [17]. Whereas Pundir et al. [11] pointed out the antibacterial activity was may be due to the production of acetic and lactic acids that lowered the $\mathrm{pH}$ of the medium or competition for nutrients, or due to the production of bacteria or antibacterial compounds.

After not the effect of Lactococcus CFS on growth of the isolates (21) of $P$. aeruginosa, the qualitative detection for isolates productivity to enzymes was measured by mixing with media method where results indicated that 6 L.P. isolates out of 8 became not L.P when exposed to CFS and just 2 stay produced, whereas 12 P.P. isolates out of 13 convert to not P.P, 1 isolate still resist the CFS of Lactococcus (Table 3).

Many researches showed the high antibacterial activity of LAB and especially Lactococcus [18-20]. Some of the researchers refer to find many acids and $\mathrm{H}_{2} \mathrm{O}_{2}$ in the medium, the released hydrogen ions during the dissociation reduce the trans membrane gradient and neutralize the proton motive force, change the internal $\mathrm{pH}$ and cause denaturation of proteins and loss of viability, however these weak acids exhibit antimicrobial activity due to the combined effect of the un dissociated molecules and the dissociated ions. Un dissociated molecules and dissociated ions induced cell damage [21,22].

The possible effect of CFS on the quantitative productivity of $P$. aeruginosa enzymes was evaluated; the study of CFS in reducing the

Table 1: The total number of $P$. aeruginosa and percentage of producing L.P and P.P

\begin{tabular}{lll}
\hline Total isolates number & L.P. isolates & P.P isolates \\
\hline 40 & 8 & 13 \\
$\%$ & 20 & 32.5 \\
\hline L.P. isolates: Lipase-producing isolates, P.P. isolates: Protease producing isolates
\end{tabular}

Table 2: Antimicrobial activity of Lactococcus CFS against (L.P. + P.P.) isolates of P. aeruginosa

\begin{tabular}{llll}
\hline Isolates number & I.Z. (mm) & Isolates number & I.Z. $(\mathbf{m m})$ \\
\hline L.P. 1 & 10 & P.P. 1 & 15 \\
L.P. 2 & 9 & P.P. 2 & 10 \\
L.P. 3 & 12 & P.P. 3 & 7 \\
L.P. 4 & 15 & P.P. 4 & 12 \\
L.P. 5 & 7 & P.P. 5 & 10 \\
L.P. 6 & 11 & P.P. 6 & 12 \\
L.P. 7 & 4 & P.P. 7 & 12 \\
L.P. 8 & 10 & P.P. 8 & 12 \\
& & P.P. 9 & 11 \\
& & P.P. 10 & 7 \\
& & P.P. 11 & 9 \\
& & P.P. 12 & 14 \\
\end{tabular}

I.Z. (mm): Inhibition zone in micrometer, L.P. isolates: Lipase-producing isolates, P.P. isolates: Protease producing isolates, P. aeruginosa: Pseudomonas aeruginosa 
enzyme produced might prove the benefit of using a CFS to council the production of enzymes, so it can reduce the virulence of pathogen bacteria.

In Table 4 we notice that all L.P. isolates were reduced after treatment with CFS, also all P.P. isolates respond to inhibition by CFS (Table 4).

In this study, we put forward the hypothesis that whether treatment with CFS has higher antimicrobial activity against $P$. aeruginosa or not. The first criteria which Lactococcus isolates should need to fulfill is that should be resistant to that particular virulence factors to avoid the direct killing of the probiotic properties. The second criteria Lactococcus has special properties make it stronger than other bacteria.

Table 3: Qualitative detection of effect the Lactococcus CFS on lipase and protease productivity of $P$. aeruginosa

\begin{tabular}{llll}
\hline L.P. & L.P.+CFS & P.P. & P.P.+CFS \\
\hline 1 & - & 1 & - \\
2 & - & 2 & - \\
3 & - & 3 & - \\
4 & - & 4 & - \\
5 & - & 5 & + \\
6 & + & 6 & - \\
7 & - & 7 & - \\
8 & - & 8 & - \\
& & 9 & - \\
& & 10 & - \\
& & 11 & - \\
& & 12 & - \\
\hline
\end{tabular}

L.P: Lipase production, P.P: Protease production, P. aeruginosa: Pseudomonas aeruginosa
In previous studies, an antimicrobial agent was conducted that the presence of organic acid acts by collapsing the electrochemical proton gradient, and $\mathrm{H}_{2} \mathrm{O}_{2}$ by peroxidation of membrane lipids thus altering the cell membrane permeability which results is disruption of substrate transport system [23-25].

The effect of Lactococcus CFS was a variety from isolate to another because it is obscure of the production levels and properties among its compounds depend on the biochemical properties of the strain used and physical and chemical conditions of growth [5,26].

\section{CONCLUSIONS}

The antimicrobial compound produced by Lactococcus was effectiveness against the test pathogen $P$. aeruginosa that used in this study. CFS was able to prevent enzymes production so it can attenuate the virulence of P. aeruginosa.

\section{RECOMMENDATIONS}

1. Since emerging reports showed increased prevalence of resistance against these drugs as observed, it seems necessary to use natural alternative (lactic acid bacteria), do as antimicrobial agents against P. aeruginosa.

2. These compounds could serve as an alternative to chemical preservatives additives used in food preservation, after checking safety of the LAB on the basis of criteria laid down by the WHO for potential probiotics, these organisms may be used as human or animal probiotics

\section{ACKNOWLEDGMENTS}

The authors would like to thank Al-Mustansiriyah University (www. uomustansiriyah.edu.iq) Baghdad-Iraq for its support in this work.

Table 4: Antimicrobial activity of Lactococcus CFS against L.P. and P.P. isolates of P. aeruginosa by (TCP-CV) method

\begin{tabular}{|c|c|c|c|c|c|}
\hline \multirow[t]{2}{*}{ Isolate number } & Without CFS & With CFS & \multirow[t]{2}{*}{ Isolate number } & Without CFS & With CFS \\
\hline & \multicolumn{2}{|l|}{ OD } & & \multicolumn{2}{|l|}{ OD } \\
\hline L.P. 1 & 0.207 & 0.09 & P.P. 1 & 0.24 & 0.015 \\
\hline L.P. 2 & 0.1 & 0.049 & P.P. 2 & 0.126 & 0.005 \\
\hline L.P. 3 & 0.122 & 0.054 & P.P. 3 & 0.166 & 0.067 \\
\hline L.P. 4 & 0.164 & 0.078 & P.P. 4 & 0.175 & 0.031 \\
\hline L.P. 5 & 0.153 & 0.086 & P.P. 5 & 0.226 & 0.087 \\
\hline L.P. 6 & 0.126 & 0.005 & P.P. 6 & 0.218 & 0.001 \\
\hline L.P. 7 & 0.115 & 0.019 & P.P. 7 & 0.13 & 0.013 \\
\hline \multirow[t]{6}{*}{ L.P. 8} & 0.151 & 0.06 & P.P. 8 & 0.1 & 0.081 \\
\hline & & & P.P. 9 & 0.251 & 0.06 \\
\hline & & & P.P. 10 & 0.261 & 0.016 \\
\hline & & & P.P. 11 & 0.175 & 0.001 \\
\hline & & & P.P. 12 & 0.1 & 0.081 \\
\hline & & & P.P. 13 & 0.142 & 0.077 \\
\hline
\end{tabular}

OD: Optical density. These numbers is the final after calculated with equation, P. aeruginosa: Pseudomonas aeruginosa

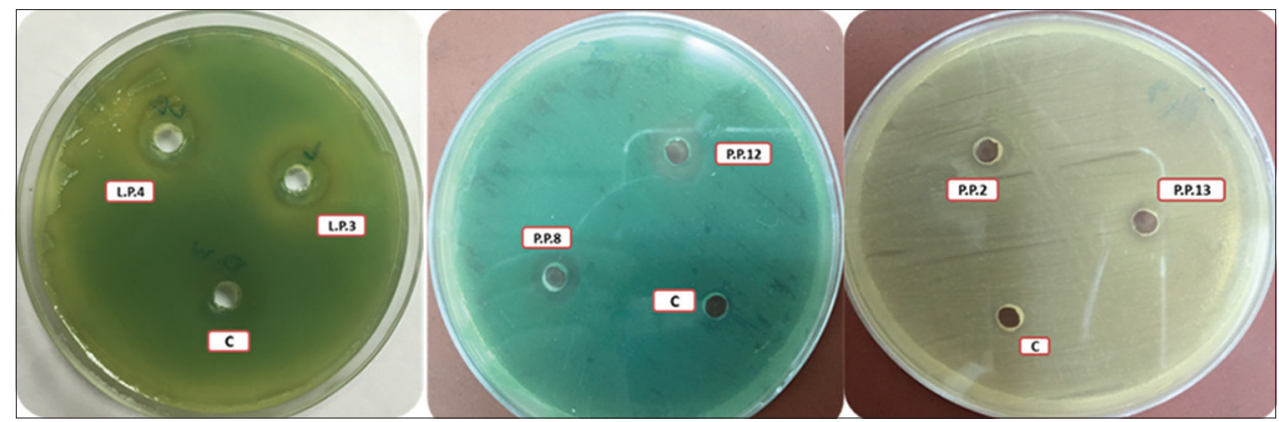

Fig. 1: Antibacterial activity of cell free supernatant of Lactococcus against Pseudomonas aeruginosa. L.P : Lipase production, P.P: Protease production, C: Control 


\section{REFERENCES}

1. Srifuengfung S, Assanasen S, Tuntawiroon M, Meejanpectch S. Comparison between Pseudomonas aeruginosa siderophores and desferrioxamine for iron acquisition from ferritin. Asian Biomed 2010;4(4):631-5

2. Kamel GM, Ezeldeen NA, El-Mishad MY, Ezzat RF. Susceptibility pattern of Pseudomonas aeruginosa against antimicrobial agents and some plant extract with focus on its prevalence in different sources. Glob Vet 2011;6(1):61-72.

3. Cornelis P, Dingemans J. Pseudomonas aeruginosa adapts its iron uptake strategies in function of the type of infections. Front Cell Infect Microbiol 2013;3:75.

4. Saxena S, Banerjee G, Garg R, Singh M, Verma S, Kushwaha R. The antibacterial efficacy of different anti pseudomonal agents against Pseudomonas aeruginosa. Int J Curr Microb Appl Sci 2014;3(11):572-5.

5. Powthong P, Suntronthiticharoen P. Antimicrobial and probiotic properties of lactic acid bacteria isolated from chicken intestine, entrails of swine and soil against gastrointestinal and urogenital pathogens. World J Pharm Pharm Sci 2013;3(1):1-18.

6. Jebur MS. Therapeutic efficacy of Lactobacillus acidophilus against bacterial isolates from burn wounds. North Am J Med Sci 2010;2(12):586-91.

7. Chowdhury A, Hossain MN, Mostazir NJ, Fakruddin M, Billah MM, Ahmed MM. Screening of Lactobacillus spp. from buffalo yoghurt for probiotic and antibacterial activity. Bacteriol Parasitol 2012;3(8):1-5.

8. Forbes BA, Sahm DF, Weissfeld AS. Baily and Scotts Diagnostic Microbiology. $12^{\text {th }}$ ed. Baltimore, USA: Mosby, Inc.; 2007. p. 266-77.

9. Johnson JR, Moseley SL, Roberts PL, Stamm WE. Aerobactin and other virulence factor genes among strains of Escherichia coli causing urosepsis: Association with patient characteristics. Infect Immun 1988;56:405-12.

10. Aminnezhad S, Kermanshahi RK, Ranjbar R. Evaluation of synergistic interaction between cell free supernatant of Lactobacillus strain and amikacin and gentamicin against Pseudomonas aeruginosa. Jundishapur J Microbiol 2015;8(4):e16592.

11. Pundir R, Rana S, Kashyap N, Kaur A. Probiotic potential of lactic acid bacteria isolated from food samples: An in vitro study. J Appl Pharm Sci 2013;3(3):85-93.

12. Al-Jassani U. Effect of Lactobacillus filtrates in growth of some Aspergillus flavus isolated and their toxins, Thesis. College of Science/ AL-Mustansiryah University; 2006.

13. Hassan NN. Effect of some microorganisms, chemical compounds and Citrullus colocynthis seed extract on the growth and composition of the biofilm of (Candida albicans). Thesis. University of Mustansiriya; 2014.
14. Chursi S, Sompetch K, Mukdee S, Jansrisewanpwong S, Srichai T, Maneenoon K, et al. Inhibition of Staphylococcus epidermis biofilm formation by traditional Thai herbal recipes used for wound treatment. J Evid Based Complementary Altern Med 2012;8:97.

15. Harrison F. Dynamic social behavior in a bacterium: Pseudomonas aeruginosa partially compensates for siderophore loss to cheats. J. Evol Biol 2013;26(6):1370-8.

16. Denkova R, Denkova Z, Yanakieva V, Radeva V, Tumbarski Y. Antimicrobial activity of Lactobacilli of human origin against Pseudomonas aeruginosa. Unive Rousse Sci J 2013;52(10):11-5.

17. Dalie DK, Deschamps AM, Richard-Forget F. Lactic acids bacteriapotential for control of mould growth and mycotoxins: A review. J Food Control 2010;21:370-80

18. Mohsin YM, Shawkat DS, Abd-Alsattar D. Novel probiotic Bifidobacterium overcomes synergistic effect of three natural biotic Omni drug and antibiotic against some UTI pathogen. Int J Sci Nat 2013;1(3):456-62.

19. Bager YM, Mohammed BB, Obaid KA, Hilal ZA. CFS of Lactobacillus: A natural agent against bacterial contamination of cosmetic toole. Int $\mathrm{J}$ Adv Biol Res 2014;4(3):258-64

20. Muhsin Y, Majeed H, Shawkat D. CFS and crude bacteriocin of Lactococcus against growth and biofilm formation for some pathogenic bacteria. Int J Curr Microb Appl Sci 2015;4(7):35-42.

21. Denkova R, Denkova Z, Yanakieva V, Blazhera D. Antimicrobial activity of probiotic Lactobacilli, Bifidobacteria and propionic acid bacteria, isolated from different sources. Microbial Pathogens and Strategies for Combating Them: Science, Technology and Education. Badajoz: Formatex Research Center; 2013. p. 857-64.

22. Abaas H, Mohammed SA, Shawkat DS, Baker YM. Effect of Lactobacillus sp. Crud bacteriocin (CB) and cell-free supernatant (CFS) against E.coli growth and adherence on vaginal epithelial cell surface. Int J Adv Res 2016;4(1):614-20.

23. Beesam S, Thirtham MR, Komireddy KR, Venkata MR. Evaluation of probiotic characteristics in certain lactic acid bacteria strains by in vitro techniques. Acta Biologica India 2012;1(2):149-51.

24. Ravaei A, Poor ZH, Salehi TZ, Tamai IA, Ghane M, Pour JD. Evaluation of antimicrobial activity of three Lactobacillus spp. against antibiotic resistance Salmonella typhimurium. Adv Stud Biol 2013;5(2):61-70.

25. Nilakhe S, Spare V. Evaluation of antimicrobial activity of probiotic micro flora from neonatal origin. Asian J Multidisc Stud 2014;2(8):182-3.

26. Jungersen M, Wind A, Johansen E, Christensen JE, Stuer-Lanridsen B, Estesen D. The science behind the probiotic strain Bifidobacterium animals subsp. Lactis BB-12. Microorganisms 2014;2(2):92-110. 